\title{
Akılcı ilaç kullanımı ilkeleri doğrultusunda diş hekimliğinde kişisel analjezik listesi oluşturulması
}

\author{
Ahmet AKICI, N. İpek KIRMIZI, Gökhan GÖÇMEN
}

\begin{abstract}
Özet
Hekimin hastayla karşılaşmadan önce hazırlık yaparak, ilgili endikasyona yönelik kendi kişisel ilaç listesini oluşturması ve bu doğrultuda hastalarının ilaçla tedavisini düzenlemesi beklenir. Hekimin bu yaklaşımı benimsemesi, akılcı ilaç kullanımının (AİK) gerekliliklerinden birisidir. Analjezikler, diş hekimlerinin (DH) en sık reçetelediği ilaç grupları arasında yer alır. Bu yazıda, "DH’lerin AİK ilkelerine uygun ilaç seçimini nasıl yapması gerektiği” üzerinde durulmaktadır. Bu işlemin daha kolay anlaşılması için diş hekimliğinde "kişisel analjezik listesi” (KAL) seçimi özelinde konunun ayrıntılarına yer verilmiştir. KAL seçimi, analjeziklere ait klinik farmakoloji bilgisinden yararlanarak "etkililik, güvenlilik, uygunluk ve maliyet"ten oluşan 4 seçim ölçütü kullanılarak yapılır. Bu sayede alternatifleri arasından en iyiler belirlenir. Böylece
\end{abstract}

DH'nin reçeteleyeceği ilaçlara ait bilmesi gereken bilgi yükü ciddi ölçüde hafifler. Piyasada mevcut çok sayıdaki analjeziği ilgilendiren bilgi yükünden kurtulur. Sadece KAL'daki sınırlı sayıdaki ilaca ait bilgileri iyice öğrenmesi kolaylaşır. Bu yöntem sayesinde az sayıdaki ilacı iyi bilen bir $\mathrm{DH}$, pratikte hem reçeteye yazacağı ilacı isabetle ve kolaylıkla belirler, hem de bu ilaçla ilgili hastasına vereceği bilgileri daha kolay aklında tutar ve bunu daha rahat hayata geçirir. Dolayısıyla, KAL sıralamasına sahip olan bir $\mathrm{DH}$, analjezik tedavisini başarılı bir şeklide düzenleme imkânına kavuşur. Analjezik özelinde kazanılacak bu akılcı yaklaşımın "transfer etkisi" yoluyla antibiyotik seçimi başta olmak üzere diş hekimliğinde ihtiyaç hissedilen diğer ilaç/ ürün gruplarının seçiminde de benimsenmesi beklenir.

Anahtar kelimeler: Diş hekimi; akılcı ilaç kullanımı; etkililik, güvenlilik, uygunluk; ilaç seçimi.
Ahmet Akıc1, N. İpek Kırmızı

Marmara Üniversitesi Tip Fakültesi Tibbi Farmakoloji Anabilim Dal, Maltepe 34854 İstanbul, Türkiye.

Gökhan Göçmen

Marmara Üniversitesi Diş Hekimliği Fakültesi Ağız, Diş ve Çene Cerrahisi Anabilim Dal, Maltepe 34854 İstanbul, Türkiye.

Corresponding Author:

Ahmet Akıc1

e-mail:aakici@marmara.edu.tr

Submitted / Gönderilme: 28.11.2016

Accepted / Kabul: 18.01.2017

How to cite this article: Akıcı A, Kırmızı Nİ, Göçmen G. Akılcı ilaç kullanımı ilkeleri doğrultusunda diş hekimliğinde kişisel analjezik listesi oluşturulması. Marmara Pharm J 2017; 21 (4): 730-740

\section{Giriş}

İlaç, sağlığı koruma, düzeltme ve yakınmaları azaltma gibi amaçlarla sıkça başvurulan kritik önemdeki bir üründür. Kullanımının akılcı ilkelere dayanması esastır. Aksi halde pek çok olumsuz sonuç ile karşılaşılabilir. Akılcı ilaç kullanımı (AİK) yarım yüzyıla yaklaşan bir süredir sağlıkla ilgili gündemi belirleyen önemli başlıklardan birisi olmayı sürdürmektedir $(1,2)$. Dünya Sağlık Örgütü (DSÖ), AİK’i "ilaçların hastaların klinik ihtiyaçlarına uygun şekilde, uygun dozlarda, yeterli sürede, kendilerine ve topluma en düşük maliyette almaları" olarak tanımlamıştır (2).

Akılcı olmayan ilaç kullanımı (AOİK), dünya genelinde olduğu gibi Türkiyede de önemli bir halk sağllğı sorunudur. İlaçların yarıya yakınının akılcı olmayan şekilde kullanıldığ bildirilmektedir $(2,3)$. Hekimlerin ilaç seçiminin yeterince akılcı olmaması, AOİK’in başlıca nedenleri arasında yer alır. $\mathrm{Bu}$ olumsuzluğun düzeltilmesi için hekimlere ve hekim adaylarına yönelik özgün AİK eğitimlerinin verilmesi gerekir. İlgili kişi ve kuruluşlar, bu yönde önerilerde bulunmakta, yol haritaları 
belirlemektedir. Örneğin, Türkiyede Sağlık Bakanlığı’nın “AİK ulusal eylem planında" ve DSÖ'nün "AİK’i yaygınlaştırma stratejilerini içeren önerilerinde", AİK eğitimlerinin hayata geçirilmesine vurgu yapılmaktadır $(4,2,5)$.

Diş hekimleri (DH), analjezikler ve antibiyotikler başta olmak üzere, alanlarına özgü çeşitli ilaçları azımsanmayacak miktarda reçete etmektedir. Örneğin, Birleşik Krallık’ta yapılan çalışmalarda yazılan tüm antimikrobiyal ilaçların \%910’unun DH'lerce yazıldığı rapor edilmiştir $(6,7)$. DH’lerin antibiyotik yazdıkları reçetelere çoğunlukla analjezik de yazma eğilimi sergiledikleri bildirilmiştir (8). Bu ilaçların istenen ölçüde akılcı kullanıldığını söylemek güçtür (9-11). Söz konusu tespitler, DH’lerin “ilaç seçimi” başta olmak üzere hastalarının ilaçla tedavisi konusunda AİK’e uygun eğitim almalarının gerekliliğine işaret etmektedir.

DH’ler açısından akılcı antibiyotik seçimi ve akılcı analjezik seçimi kritik iki başlı̆̆ı oluşturmaktadır. Antibiyotiklerin akılcı kullanılmasına dair DH'lerin yararlanabileceği ulusal ve uluslararası düzeyde nispeten daha çok kaynakla karşılaşılabilmektedir $(9,12-14)$. Diş hekimliğinde analjeziklerin özellikle akılcı seçimine ilişkin detaylı somut bilgi sunan kaynaklara ihtiyaç duyulmaktadır. Bu yazıda AİK ilkeleri çerçevesinde DH'lerin kişisel analjezik listesi (KAL) oluşturmasına yardımcı olacak yaklaşım üzerinde durulmuştur. $\mathrm{Bu}$ yaklaşımın gerektirdiği "analjeziklerin klinik farmakolojisi” bilgisine de yazıda yer verilmiştir. "KAL oluşturma" işleminin daha kolay anlaşılması için, yöntemin ayrıntıları bir stajyer DH'nin bu yolla KAL seçimi örneği üzerinden simülasyonla sirasiyla sunulmuştur. Okuyucuya seçilecek ilaç konusunda herhangi bir yönlendirme bulunulmaması bakımından bu simülasyon yöntemi özellikle tercih edilmiştir.

\section{Kişisel Tedavi ve Kişisel İlaç Listesi Hazırlama}

İlgili her bir hastalığın tedavisinde alternatifleri arasından önceden hazırlıkla, objektif değerlendirmeler yapılarak hekim tarafından belirlenen ve yeğlenen tedaviye kişisel tedavi (K-tedavi) denir. Kişisel ilaç (K-ilaç), içerisinde ilacın bulunduğu K-tedavinin kullanılacağı bir endikasyonda hekimin henüz hasta ile karşılaşmadan önce o endikasyon için belirlediği ve öncelik sırasına göre sıraladığı ilaç listesindeki en üst sıralarda bulunan ilaçlara verilen addır. K-ilaç, aynı zamanda K-tedavinin bir bileşenini oluşturur. İlaç tedavisi düzenleyen her hekim, AİK ilkelerine göre sık karşılaştığ 1 endikasyonlara öncelik vermek koşuluyla önceden kendisinin belirlediği, K-tedavisini ve bu tedavinin gerektirdiği K-ilaç seçimini yapmalıdır. Hastasının ilaçla tedavisini düzenleme kararı aldığında da bu K-tedavinin (aynı zamanda bunun içerdiği K-ilacın) o hasta için uygunluğunu kararlaştırıp tedavi sürecini başarıyla yönetmelidir $(1,12,15)$.

Hekim "akılcı tedavide eniyileme analizi" (ATEA) yaparak K-tedavi ve K-ilaç belirleme işlemini rahatlıkla yapabilir. ATEA, günlük hayatta herhangi bir ihtiyacın giderilmesi için yapılan bilinçli seçim ölçütlerinin kullanımına benzemesinden dolayı, uygulanabilirliği oldukça kolaydır. ATEA işlemi etkililik, güvenlilik, uygunluk ve maliyet seçim ölçütlerinden yararlanılarak yapılır. AİK ilkeleri doğrultusunda hareket eden hekim, karşılaşabileceği hastalıkların tedavisi için K-tedavi ve K-ilaç listesini oluşturur. Hasta başı tedavide, bu ilaçlardan yararlanır. Şayet ilaç tedavisi kararı alırsa, o sırada yapacağı kısa bir değerlendirme ile karşısındaki hastaya K-ilaç listesindekiler arasında en uygun olan(lar)1 seçer ve reçetesini yazar $(1,15)$.

Hekim tedavi ve ilaç seçimini, AİK ilkeleri doğrultusunda, kendi "kişisel" yetkinliği içerisinde, kanıta dayalı bilgiden beslenerek gerçekleştirilir. Başlangıçta biraz zaman alabilen bu işlemlerin, en sık karşılaşılan endikasyonların tedavisi için başlatılması pratik yararlar sağlar. K-ilaç seçimini titiz şekilde isabetle yapan bir hekim, aynı endikasyonda benzer hastalar için her seferinde "ilaç seçimi işlemini" tekrar tekrar yapmak zorunda kalmaz. Bu sayede hastaya uygunsuz ilaç verilmesi riski en aza indirilebilir, hastanın zarar görmesi önlenir ve hekim gereksiz iş yükünden, zaman ve özgüven kaybından korunmuş olur $(1,15)$.

K-ilaç, "etkililik, güvenlilik, uygunluk ve maliyet" bakımından sahip olduğu özellikleri sayesinde kendisini hekime kabul ettirmiş bir üründür ve kıymetlidir. Bu bakımdan seçtiği K-ilacını değiştirmek için hekim tatminkâr ve güçlü kanıtlara ihtiyaç duyar. Ürün tanıtım elemanlarının, hastaların veya diğer unsurların herhangi bir başka ilacı yazdırma/seçme baskılarına karşı direnme gücüne sahip olur (1).

ATEA işlemi sırasında oluşturulacak basit bir tabloda ilgili endikasyonun gereksinim duyduğu tedavi/ilaç seçimin seçim ölçütlerinden ne oranda etkilendiği, objektif değerlendirme yapılarak tespit edilebilir. Buna göre ilgili endikasyonda her bir seçim ölçütünün "belirleyici gücü" saptanır. Ardından alternatifleri oluşturan her bir ilaç özelinde bu 4 seçim ölçütünün her birini karşılama performansı her ilaç için ayrı ayrı saptanır. Bu işlem sırasında ilaçların klinik farmakoloji bilgilerinden somut biçimde yararlanılır. Söz konusu seçim ölçütlerinin her biri bakımından en avantajlı olan alternatif en yüksek puanla, en az avantaja sahip olan ise en düşük puanla değerlendirilir. ATEA ile ilaç seçiminin isabetli 
yapılabilmesi için bu ölçütlerin neleri kapsadığının bilinmesi gerekir $(1,15)$.

a-Etkililik: İlacın kullanılma gerekçesini tam olarak karşılayan ölçüttür. Planlanacak tedavi hedefinin yakalanmasına ne ölçüde yardımcı olduğu dikkate alınarak belirlenir. Bu ölçütte ilacın farmakodinamik (daha çok) ve farmakokinetik özellikleri belirleyicidir.

b-Güvenlilik: İlaç yan etki /karşıt etki görülme sıklığı, bu sorunların tıbbi açıdan taşıdı̆̆ı şiddet/ciddiyet durumu ve bu bakımdan potansiyel riskin/sağlanacak yarara oranının boyutu güvenliliği belirler.

c-Uygunluk: İlacın uygunluğunu çok çeşitli unsurlar belirleyebilir. Örneğin ilacın kontrendikasyonları, kullanım kolaylığı, kullanım sıklığının az veya çok olması, erişim kolaylığı, ilaç-ilaç etkileşimi, ilaç-besin etkileşimi, hastanın komorbiditesi, yaşı, hamilelik ve emzirme durumu vb, özel hasta gruplarında kullanım kolaylığı/zorluğu bulunup bulunmaması, enteral/parenteral kullanımlar vb. bu ölçütte belirleyicidir. Kullanım koşullarını zorlayan her bir unsur ve bunun alt kırılımları, uygunluk açısından değer yitirilmesine yol açar.

d-Maliyet: Listedeki aday ilaçların tedaviyi sağlamada ortaya koydukları toplam maliyet üzerinden hesaplanır. Dental tedavilerde çoğu kez bu, reçeteye yazılması düşünülen ilacın bir seferde eczaneden alınan miktarının maliyeti kadardır.

ATEA’nın anlaşılabilirliğini kolaylaştırmak için söz konusu seçim ölçütlerinin kullanıldığı teknik detaylar Tablo 1'de sunulmuştur. Bu işlemlere aşama aşama aşağıda yer verilmiştir: $(1,15)$

- ATEA için 7 sütunlu bir tablo yapılmıştır. Tablonun ilk sütunu seçime katılacak ilaç adayları için, izleyen 4 sütun etkililik, güvenlilik, uygunluk ve maliyet için, diğer sütun toplam değerlendirme puanı için, son sütun ise sıralamanın yazılması için kullanılmıştır.

- Tablo 1'de ilk satırda yer alan 4 seçim ölçütünün (etkililik, güvenlilik, uygunluk ve maliyet) ağırlıklı puanları belirlenir. Buna göre ilgili endikasyonda (bu yazıda analjezik ihtiyacı duyulan diş ağrısı örneğinde) sorunun çözümü için kullanacak müstakbel en iyi analjezik ilacın seçimini etkileme payları belirlenir. Her bir faktörün seçimi etkilemedeki gücüne 100 tam puan üzerinden karar verilir (Simüle olguda stajyer DH, bu puanlamayı Tablo 2'de sırasıyla, 30, 25, 30 ve 15 puan olarak belirlemiştir).

- Tablo 1'de küçük kutucukların her birinin içinin puanlaması öncesi, seçime katılacak tüm analjezik adayları, ilk sütunda alt alta, her bir satıra bir aday gelecek şekilde listelenir (Simüle olguda örnek işlemin çok uzatılmaması bakımından stajyer DH, bu sütuna Tablo 2'de sunulan, Türkiye'deki kısa ürün bilgisinde (KÜB) ilacın endikasyonu bölümünde "diş ăgrısı" bulunan non steroidal anti inflamatuvar ilaçları (NSAİI) ve parasetamol'ü dahil etmiştir ).

- Her bir analjezik ilaç adayının satırında sırayla karşılaşılan kutucukta ilgili seçim ölçütünü karşılama gücü bakımından en iyiyi arama puanlaması yapılır. Buna göre her bir kutucuğa sütun başında yazılı ölçütü karşılama bakımından en başarısızdan en başarılısına doğru "0 ile 10" arası puanlar verilir. Bu sırada her bir kutucuk diğerlerinden bağımsız olarak değerlendirilir. Yani etkililik puanlanırken o ilacın güvenliliği ya da uygunluğu dikkate alınmaz (Simüle olguda stajyer DH, Tablo 2'de yer verdiğ $i$ her bir ilaç için 0-10 arası puanlar vermiştir. Örneğin parasetamol’ün etkililiğine 9, güvenliliğine 9, uygunluğuna 9 ve maliyetine 10 puan vermiştir).

- Tablo 1'deki tüm kutucukların "0 ile 10" arası puanlama işlemi tamamlanır. Ardından ilk başta sütunlarda 4 ölçüte verilen puanlarla bu kutucuklarda yer alan puanlar çarpılır. Çıkan rakamlar kutucukların o endikasyon özelinde aldığı nihai kutucuk puanıdır. Tüm analjeziklerin her bir kutucuğunun nihai puanları bu yolla belirlenir. (Simüle olguda stajyer DH, Tablo 2'de yer verdiği her bir analjezik için bu çarpma işlemini tamamlamıştır. Örneğin parasetamolün nihai kutucuk puanlamaları etkililikte (9 x30 = 270 puan), güvenlilikte (9 $\times 25=225$ puan), uygunlukta $(9 \times 30=270)$ ve maliyette $(10 \times 15=150$ puan $)$ belirlenmiştir $)$.

- Tablo 1'deki tüm kutucukların puanlamasının tamamlanmasının ardından her bir analjeziğin almış olduğu 4 kutucuk toplam puanı (etkililik + güvenlilik + uygunluk + maliyet) belirlenir (Simüle olguda stajyer DH, Tablo 2'de parasetamolün toplam puanını 915 olarak belirlenmiştir).

- Tablo 1'de son sütunda her bir analjeziğin toplam puanı belirlendikten sonra bu puanlar siralamaya tabi tutularak en yüksek puanı almış olan analjezik ilaç sıralaması, yani KAL ortaya çıkartılır. Bu yolla en üst sıralara yerleşen analjezik ilaçlar, ATEA yöntemine göre bu endikasyon için en iyi ilaçlar unvanını alır. Bu sıralamada en yüksek puanı almış olan ilaç, seçimi yapan hekimin o endikasyonda K-ilacı unvanını almış olur (Simüle olguda stajyer DH, Tablo 2'de en yüksek puanı (915 puan) parasetamole vermiştir. Buna göre "diş ă̆rısı"nda analjezik reçeteleme kararı aldiğında, hasta başı yapacağı son uygunluk sorgulaması öncesinde stajyer DH'nin K-ilacı, parasetamol olmuştur). 
Tablo 1. Diş ağrısı tedavisinde analjezik ilaç seçiminin eniyileme yöntemiyle belirlenmesi.

\begin{tabular}{|c|c|c|c|c|c|c|}
\hline Ölçüt puanı & 30 & 25 & 30 & 15 & 100 & \multirow{2}{*}{ Siralama } \\
\hline İlaçlar & Etkililik & Güvenlilik & Uygunluk & Maliyet & Toplam & \\
\hline Analjezik A & $\begin{array}{c}8 \\
(8 \times 30=240)\end{array}$ & $\begin{array}{c}8 \\
(8 \times 25=200)\end{array}$ & $\begin{array}{c}7 \\
(7 \times 30=210)\end{array}$ & $\begin{array}{c}7 \\
(7 \times 15=105)\end{array}$ & 755 & 3 \\
\hline Analjezik B & $\begin{array}{c}9 \\
(9 \times 30=270)\end{array}$ & $\begin{array}{c}9 \\
(9 \times 25=225)\end{array}$ & $\begin{array}{c}9 \\
(9 \times 30=270)\end{array}$ & $\begin{array}{c}8 \\
(8 \times 15=120)\end{array}$ & 885 & \\
\hline Analjezik C & $\begin{array}{c}9 \\
(9 \times 30=270)\end{array}$ & $\begin{array}{c}9 \\
(9 \times 25=225)\end{array}$ & $\begin{array}{c}8 \\
(8 \times 30=240)\end{array}$ & $\begin{array}{c}6 \\
(6 \times 15=90)\end{array}$ & 825 & 2 \\
\hline
\end{tabular}

( Tablodaki simülasyonda herhangi bir yönlendirmede bulunmamak için puanlama işlemi sırasında herhangi bir ilaç adı açıça kullanılmamaya özen gösterilmiştir. Ölçüt satırının puanlamasında ise takip kolaylı̆̆ı açısından Tablo 2'de simülasyonu yapılan stajyer DH'nin puanlaması" alıntılanmıştır).

Tablo 2. Pulpitise bağlı tekrarlayan diş ağrısı (tekrarlayan dental işlemlere rağmen geçmeyen), tedavisinde analjezik ilaç seçiminin eniyileme yöntemiyle belirlenmesi.

\begin{tabular}{|c|c|c|c|c|c|c|}
\hline \multirow{2}{*}{ Ölçüt puanı } & 30 & 25 & 30 & 15 & 100 & \multirow{2}{*}{ Siralama } \\
\hline & Etkililik & Güvenlilik & Uygunluk & Maliyet & Toplam & \\
\hline Naproksen & $\begin{array}{c}10 \\
(10 \times 30=300)\end{array}$ & $\begin{array}{c}8 \\
(8 \times 25=200)\end{array}$ & $\begin{array}{c}8 \\
(8 \times 30=240)\end{array}$ & $\begin{array}{c}7 \\
(7 \times 15=105)\end{array}$ & 845 & 3 \\
\hline Asetilsalisilik asit & $\begin{array}{c}10 \\
(10 \times 30=300)\end{array}$ & $\begin{array}{c}5 \\
(5 \times 25=125)\end{array}$ & $\begin{array}{c}6 \\
(6 \times 30=180)\end{array}$ & $\begin{array}{c}9 \\
(9 \times 15=135)\end{array}$ & 740 & 7 \\
\hline Diklofenak & $\begin{array}{c}10 \\
(10 \times 30=300)\end{array}$ & $\begin{array}{c}7 \\
(7 \times 25=175)\end{array}$ & $\begin{array}{c}6 \\
(6 \times 30=180)\end{array}$ & $\begin{array}{c}6 \\
(6 \times 15=90)\end{array}$ & 745 & 6 \\
\hline Deksketoprofen & $\begin{array}{c}10 \\
(10 \times 30=300)\end{array}$ & $\begin{array}{c}7 \\
(7 \times 25=175)\end{array}$ & $\begin{array}{c}7 \\
(7 \times 30=210)\end{array}$ & $\begin{array}{c}5 \\
(5 \times 15=75)\end{array}$ & 760 & 5 \\
\hline Diflunisal & $\begin{array}{c}10 \\
(10 \times 30=300)\end{array}$ & $\begin{array}{c}7 \\
(7 \times 25=175)\end{array}$ & $\begin{array}{c}8 \\
(8 \times 30=240)\end{array}$ & $\begin{array}{c}4 \\
(4 \times 15=60)\end{array}$ & 775 & 4 \\
\hline İbuprofen & $\begin{array}{c}10 \\
(10 \times 30=300)\end{array}$ & $\begin{array}{c}9 \\
(9 \times 25=225)\end{array}$ & $\begin{array}{c}8 \\
(8 \times 30=240)\end{array}$ & $\begin{array}{c}7 \\
(7 x 15=105)\end{array}$ & 870 & 2 \\
\hline Parasetamol & $\begin{array}{c}9 \\
(9 \times 30=270)\end{array}$ & $\begin{array}{c}9 \\
(9 \times 25=225)\end{array}$ & $\begin{array}{c}9 \\
(9 \times 30=270)\end{array}$ & $\begin{array}{c}10 \\
(10 \times 15=150)\end{array}$ & 915 & \\
\hline
\end{tabular}

( ${ }^{*}$ Tablodaki simülasyonda herhangi bir yönlendirmede bulunmamak için puanlama işlemi bir stajyer DH’nin puanlaması”olarak sunulmuştur. Stajyer DH listesine NSAIII'lerden hakkında yeterli bilgiye sahip olduklarını ve parasetamolü dahil etmeyi uygun bulmuştur. Bu nedenle söz konusu simülasyondan içeriği için değil, öncelikli olarak yöntemin kavranması amacıyla yararlanılmalıdır).

DH'lerin KAL oluşturma hazırlı̆̆ının yukarıdaki işlemeler doğrultusunda daha kolay yapılabilmesi ve daha anlaşılır kılınması için aşağıda analjezik ilaçların klinik farmakolojilerine ait bazı bilgilere de bu yazıda yer verilmiştir. Bu kapsamda analjeziklerin farmakolojisi ile ilgili kısa bilgilerin ardından bu ilaçların etkililiğini belirlemede yararlanılan farmakodinamik özellikleri, güvenlilikleri, uygunlukları ve 2016 yılı Kasım ayı itibarıyla kamu satış fiyatı özelinde ilaç kutu maliyetleri bilgilerine yer verilmiştir.

\section{Analjeziklerin Klinik Farmakolojisi}

Diş hekimliğinde analjeziklerin akılcı kullanılabilmesi için ilk olarak analjezik ihtiyacını meydana getiren ağrının iyi tanımlanması gerekmektedir. Ağrı çeşitli şekillerde sınıflandırılabilir. En basit şekliyle üç grupta ele alınabilir. Bunlar, zararlı akut uyaranlar ile oluşan fizyolojik nosiseptif ağrı, doku inflamasyonu veya yaralanması ile oluşan patofizyolojik nosiseptif ağrı ve periferal veya santral kaynaklı nöropatik ağrı olarak sınıflandırılabilir (16). Diş hekimliği pratiklerinde, hastalar açısından rahatsız edici bu uyaranın 
çoğu kez etkin dental işlemler ile giderilmesi mümkündür. Bununla birlikte bazı hastaların analjezik ilaç kullanmasını da gerektirecek kadar ağrı yakınması olabilir.

Analjezikler diş hekimliğinde daha çok geçici bir önlem olarak, operatif işlem yapılıp etken unsurlar bastırılıncaya kadar (genelde 1-7 gün) ağrının yatıştırılması için kullanılır (17). Karmaşık ve farklı mekanizmaların birbirleri ile etkileşim içinde olduğu ağrı konusunda diş hekimliği pratiğinde kullanılabilecek analjezik ilaçlar 3 ana kategoride toplanabilir (16-20). Bunlar;

1. Non-steroidal anti-inflamatuar ilaçlar (NSAİI)

2. Non-opioid, non-NSAIII'ler

3. Opioid ilaçlar.

$\mathrm{Bu}$ bölümde diş hekimliğinde analjeziklerin klinik farmakolojisi, yukarıda değinilen AİK’e uygun KAL hazırlama yaklaşımına katkı sunacak çerçevede ele alınmıştır. Buna göre analjeziklerin her bir ana grup ve alt grupta yer alan, diş hekimliğinde kullanılan analjezik ilaçlar konusunda öncelikle kısa tanımlayıcı farmakoloji bilgisi sunulmuştur. Ardından her bir ilaç için KAL seçiminde kullanılan ATEA’nın gerektirdiği "etkililik, uygunluk, güvenlik ve maliyet" ile ilgili bilgilere yer verilmiştir.

\section{NSAIII'lerin Klinik Farmakolojisi}

\section{1.a. Farmakodinami ve Farmakokinetiği}

NSAIII'ler genelde mevcut ağrıyı kesmek ve/veya inflamasyon sonucu gelişen semptomları baskılamak (antiinflamatuar etki) amacıyla sıkça reçete edilen ilaç grupları arasındadır. NSAIII'lerin analjezik/antiinflamatuar etkilerinin yanı sıra antipiretik ve antiagregan etkileri de bulunmaktadır. Çoğu NSAIII etkilerini araşidonik asidi prostoglandinlere çeviren siklooksijenaz (COX) enzimlerini non-selektif şekilde inhibe ederek gösterir $(18,20-22)$. Böylelikle hiperaljeziye neden olan PGI2 (prostaglandin $\mathrm{I}_{2}$ ) ve PGE2 (prostaglandin $\left.\mathrm{E}_{2}\right)$ gibi prostanoidlerin oluşumu engellenir $(22,23)$. COX enzimlerinin inhibisyonu, aynı zamanda ağrıya da neden olan kızarıklık, 1sı artışı ve şişlik gibi sorunların tedavisine katkı sağlar (22). NSAİ́’ler fizyolojik önemi olan COX1'i ve inflamasyonda indüklenen COX-2'yi inhibe ederler. Bazılarının (selekoksib gibi) COX-2'ye selektivitesi yüksektir. Aspirin, diğer NSAIİ’lerden farklı olarak siklooksijenazı asetilleyerek bunu geriye dönüşümsüz olarak bloke eder (22).

NSAİI’lerkimyasalyapılarınagöreçokçeşitlisınıflandırmalara tabi tutulabilmektedir. ATC (Anatomik, terapötik, kimyasal sistem) sınıflamasına göre bu ilaçlar yaklaşık 10 alt grupta incelenebilir (16, 17, 21-25). Bunlardan 7 alt gruptaki çeşitli ilaçlar halen Türkiyede piyasada mevcuttur (Tablo 3). Etki sürelerine göre yapılan sinıflandırmalarda ise kısa, orta ve uzun etkili NSAIİ'lerden söz edilebilir. Buna göre, ibuprofen, aspirin ve diklofenak gibi NSAIİ'ler kısa etkili (yarı ömürleri 4 saatten kısa), diflunisal ve naproksen gibiler orta etki süreli (yarı ömürleri 8-14 saat) ve piroksikam (yarı ömrü 57 saat) gibiler ise uzun etki sürelidir $(17,21,22,25,26)$.

Tablo 3. Nonsteroidal anti-inflamatuar ilaçların (NSAİI) sınıflandırılması (ATC, anatomik terapötik, kimyasal sistem siniflamasi).

\begin{tabular}{|c|c|c|}
\hline \begin{tabular}{|l|} 
NSAIII Grubu \\
\end{tabular} & NSAIII Farmakolojik Adı ${ }^{*}$ & ATC Kodu \\
\hline \multirow{3}{*}{$\begin{array}{l}\text { Salisilik asit ve } \\
\text { türevleri }\end{array}$} & Asetilsalisilik asit (Aspirin) & N02BA01 \\
\hline & Salsalat & N02BA06 \\
\hline & Diflunisal & N02BA11 \\
\hline \multirow{8}{*}{$\begin{array}{l}\text { Asetik asit } \\
\text { türevleri ve } \\
\text { benzerleri }\end{array}$} & Aseklofenak & M01AB16 \\
\hline & Diklofenak & M01AB05 \\
\hline & Etodolak & M01AB08 \\
\hline & Asemetazin & M01AB11 \\
\hline & İndometazin & M01AB01 \\
\hline & Sulindak & M01AB02 \\
\hline & Tolmetin & M01AB03 \\
\hline & Ketolorak & M01AB15 \\
\hline \multirow{4}{*}{ Oksikamlar } & Piroksikam & M01AC01 \\
\hline & Tenoksikam & M01AC02 \\
\hline & \begin{tabular}{|l|} 
Lornoksikam \\
\end{tabular} & M01AC05 \\
\hline & Meloksikam & M01AC06 \\
\hline \multirow{7}{*}{$\begin{array}{l}\text { Propionik asit } \\
\text { türevleri }\end{array}$} & İbuprofen & M01AE01 \\
\hline & Naproksen & M01AE02 \\
\hline & Ketoprofen & M01AE03 \\
\hline & Flurbiprofen & M01AE09 \\
\hline & Tiaprofenik asit & M01AE11 \\
\hline & Oksaprozin & M01AE12 \\
\hline & Deksketoprofen & M01AE17 \\
\hline Fenamatlar & Mefenamik asit & M01AG01 \\
\hline $\begin{array}{l}\text { Koksibler (COX-2 } \\
\text { selektif) }\end{array}$ & Selekoksib & M01AH06 \\
\hline Diğer & Nimesulid & M01AX17 \\
\hline
\end{tabular}

* Halen Türkiye pazarında mevcut olan NSAIII'lere yer verilmiştir.

NSAIII’ler hafif-orta şiddette diş ağrısını ve inflamasyonu hafifletmekteçoğunlukla etkilidirler(17). Türkiyédepazarlanan ve kısa ürün bilgisìnde (KÜB) "diş ağrısı", "dental tedavi” veya "dental ameliyatı takiben" vb. endikasyonları bulunan NSAIII'ler ibuprofen, asetilsalisilik asit, deksketoprofen, diflunisal, diklofenak ve naproksen'dir (Tablo 4). Kuşkusuz bu ilaçlar dışındaki diğer bazı NSAIII’ler de diş hekimliğinde bazı durumlarda kullanılabilmektedir. Bunların KÜB’lerinde pek çok diş ağrısını da kapsayacak biçimde "hafif-orta dereceli 
Tablo 4. Parasetamol ve nonsteroidal anti-inflamatuar ilaçların (NSAİ̇) yarılanma ömürleri ve günlük kullanım dozları (“Dental problemlerde kullanıldığı kısa ürün bilgisinde belirtilenler" Tabloya alınmıştır).

\begin{tabular}{|c|c|c|}
\hline NSAİİ adı & Yarı ömrü & Kullanım dozları \\
\hline$\underset{(18,22,25)}{\text { Parasetamol }}$ & $2-3$ saat & $\begin{array}{l}\text { - 325-1000 mg 4-6 saat arayla (maksimum } 4000 \mathrm{mg} / \text { gün, erişkin), (kronik alkol problemi olanlarda, } \\
\text { karaciğer hastalığı olanlarda ve çocuklarda maksimum } 2000 \mathrm{mg} \text { ). } \\
\text { - Çocuk: 40-480 mg ( veya 10-15 mg/kg) maksimum } 5 \text { kere/gün }\end{array}$ \\
\hline $\begin{array}{c}\text { İbuprofen } \\
(17,18,20,22)\end{array}$ & $2-4$ saat & 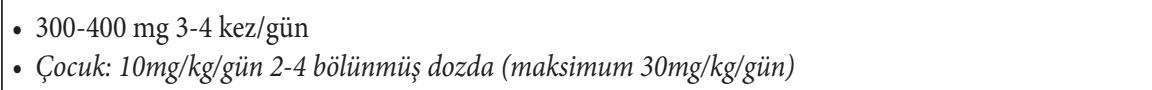 \\
\hline$\underset{(27)}{\text { Deksketoprofen }}$ & $2-3$ saat & $\begin{array}{l}\text { - 4-6 saatte bir } 12,5 \mathrm{mg} \text { veya } 8 \text { saatte bir } 25 \mathrm{mg} \text { (maksimum günlük doz } 75 \mathrm{mg} \text { ), yaşlılarda günlük doz } \\
\text { en fazla } 50 \mathrm{mg} \text {. } \\
\text { - Çocuklarda kullanılması tavsiye edilmez. }\end{array}$ \\
\hline$\underset{(17,18,22)}{\operatorname{Naproksen}}$ & 14 saat & $\begin{array}{l}\text { - } 250 \mathrm{mg} 4 \text { kez/gün veya } 500 \mathrm{mg} 2 \mathrm{kez} / \text { gün } \\
\text { - Çocuklarda kullanılması tavsiye edilmez. Zorunlu hallerde kısa süreliğine } 5 \mathrm{mg} / \mathrm{kg} \text { günde } 2 \text { kez. }\end{array}$ \\
\hline$\underset{(17,18,22)}{\text { Diklofenak }}$ & $1-2$ saat & $\begin{array}{l}\text { - } 50 \mathrm{mg} 3 \mathrm{kez} / \mathrm{gün}, 75 \mathrm{mg} 2 \mathrm{kez} / \mathrm{gün} \\
\text { - Çocuklarda kullanılması tavsiye edilmez. Zorunlu hallerde kısa süreliğine; operasyon sonrası 0,5-2 mg } \\
\text { /kg/gün bölünmüş dozlar (maksimum } 150 \mathrm{mg} \text { ). }\end{array}$ \\
\hline$\underset{(17,22,25)}{\text { Asetil salisilik asit }}$ & $\begin{array}{l}15 \mathrm{dk}-3 \text { saat } \\
\text { (yüksek dozlarında } \\
\text { 15-30 saate çıkabilir) }\end{array}$ & $\begin{array}{l}\text { - 4-6 saat arayla } 325-650 \mathrm{mg} \\
\text { - Çocuk: 4-6 saat arayla } 10 \mathrm{mg} / \mathrm{kg} \text {. }\end{array}$ \\
\hline$\underset{(17,22,25)}{\operatorname{Diflunisal}}$ & $8-13$ saat & $\begin{array}{l}\text { - 8-12 saat arayla } 250-500 \mathrm{mg} \text {. } \\
\text { - Çocuklarda kullanılmasi tavsiye edilmez. }\end{array}$ \\
\hline
\end{tabular}

ağrıda endikedir" ifadesi mevcuttur. Benzer şekilde bazı analjeziklerin KÜB'lerinde "post-operatif ağrida endikedir" ifadesi bulunmaktadır. Dolayısıyla KÜB’ünde bu ifadeleri barındıran analjeziklerin de diş ağrısında/dental operasyon sonrası ağrı tedavisinde kullanılabileceği varsayılır. Ancak analjezik seçimine metodolojik bilgi vermeyi önceleyen bu yazıda alternatif ilaç sayısı sınırlı tutulmaya çalışılmıştır. Bu nedenle ilaç seçim ölçütleri tartışılırken gereksinim duyulan bilgi amaçlı yazıda sadece KÜB’ünde "diş ağrısı", "dental tedavi" veya "dental ameliyatı takiben" endikasyonları bulunan NSAİI’ler ile yetinilmiştir. Parasetamol gibi diğer analjezikler için de benzeri yaklaşım sergilenmiştir.

\section{1.b. Güvenliği}

NSAIII'lerin en sık rastlanan karşıt etkisi COX-1 enzim inhibisyonundan ileri gelen, gastrointestinal sistemi (GİS) etkileyen belirtilerdir $(22,23,25)$. Düzenli nonselektif NSAİ̇ kullananların \%15-30'unda endoskopik incelemelerde gastrik veya duodenal ülser geliştiği bildirilmiştir $(28,29)$. Geçirilmiş veya aktif peptik ülseri olan hastalar nonselektif NSAIII kullanmamalıdır. GİS hasarı riski en düşük selektif olmayan NSAIII ibuprofendir. Piroksikam ve ketorolak gibi NSAIII’lerde ise bu risk yüksektir $(23,30)$.
NSAIII’ler başta böbrek sorunlarına yol açma olmak üzere böbrek ve karaciğer işlevlerini bozabilir. Böbrek, karaciğer bozukluğu olan hastalarda zorunlu hallerde NSAIII kullanımının oldukça dikkatli yapılması ve bilhassa böbrek işlevlerinin izlenmesi gerekir $(22,30)$.

Önemli bir kısmı için kesin olarak kanıtlanmamış olsa da "asetilsalisilik asit haricindeki NSAIII’lerin kardiyovasküler risk oluşturduğu" yönündeki tartışmalar sürmektedir. $\mathrm{Bu}$ advers etki PGI2 (prostaglandin $\mathrm{I}_{2}$ ) ve TxA2 (tromboksan $\mathrm{A}_{2}$ ) dengesinin bozulması ile ilişkilendirilmiştir. $\mathrm{Bu}$ ilişkilendirmenin akabinde rofekoksib ve valdekoksib piyasadan çekilmiş, Avrupa İlaç Ajansı ve Amerikan Gıda ve İlaç İdaresi konu ile ilgili önlemler almıştır $(23,31)$. Türkiye'de de bu yönde düzenlemelere gidilmiş ve söz konusu ilaçlar piyasadan çekilmiştir (1). Ayrıca NSAIII’lerin kan basıncını olumsuz yönde etkileyebildiği bilinmektedir $(25,32)$. Başta asetilsalisilik asit olmak üzere NSAİ́’ler kanama riskini arttırırlar. Dişe yönelik girişim öncesi verilen analjeziğin, ameliyat/girişim sonrası kanamayı artırmaması istenir (17). Bu bakımdan dikkatli olunması gerekir. Astım ve alerji durumlarında da NSAIII'lerin olumsuz etkileri ile daha belirgin şekilde karşılaşılabilinir (17, 22, 23), (Tablo 5). 
Tablo 5. Nonsteroidal anti-inflamatuar ilaçların sık rastlanan ya da ciddi olabilen bazı karşıt etkileri ve uygunluk sorunları (1, $16,17,20,22,25-29)$.

\begin{tabular}{|c|c|}
\hline $\begin{array}{l}\text { Etkilenen önemli yerler/ } \\
\text { yapılar }\end{array}$ & Karşıt etkiler / Uygunluk sorunları \\
\hline $\begin{array}{l}\text { Gastrointestinal sistem } \\
\text { (GİS) }\end{array}$ & $\begin{array}{l}\text {-Karın ağrısı, bulantı, dispepsi, asit salınımında artış, mukozada hasar, GİS ülserleri ve kanamalar, iştahsızlık, diyare. } \\
\text {-Karaciğer hasarı } \\
\text {-Hastada sigara ve alkol kullanımı GİS yakınmalarını şiddetlendirir. } \\
\text {-Nonselektifler peptik ülserli hastalarda kontrendikedir. }\end{array}$ \\
\hline $\begin{array}{l}\text { Böbrekler ve } \\
\text { kardiyovasküler sistem }\end{array}$ & $\begin{array}{l}\text {-Tuz/su retansiyonu, ürat atılımının azalması, analjezik nefropatisi. } \\
\text {-Selektif COX-2 inhibitörleri miyokard enfarktüsü, inme vb. trombotik olay riskini artırmaktadır. Bu risk nonselektif } \\
\text { NSAİ̇’lerde de düşük oranda bulunmaktadır. } \\
\text {-Ağır konjestif kalp yetmezliğinde tüm NSAİ̇'ler kontrendikedir. } \\
\text {-Antihipertansif/diüretik ilaçların etkisinin azalması vd. bazı etkileşimler. }\end{array}$ \\
\hline Santral sinir sistemi & $\begin{array}{l}\text {-Baş ağrısı, vertigo, depresyon, konfüzyon, kulak çınlaması, hiperventilasyon (salisilatlar). } \\
\text {-Reye sendromu. }\end{array}$ \\
\hline Hematolojik sistem & $\begin{array}{l}\text {-Kanama riskinde artış, morarmaya eğilim, trombosit aktivasyonunun inhibisyonu, anemi, agranülositoz. } \\
\text {-Antikoagülan etki aspirinle geri dönüşümsüz, diğerlerinde geri dönüşümlü COX-1’in inhibisyonuyla gerçekleşir. } \\
\text {-Varfarin kullananlarda etkileşime girerek antikoagülan etkinin şiddetlenmesine ve kanamalara yol açabilirler. } \\
\text {-Kanama riski nedeniyle cerrahi girişimlerden önce kesilmeleri gerekir. }\end{array}$ \\
\hline İmmun sistem & -Aşırı duyarlılık, kızarıklık, döküntü, ürtiker, bronkospazm, astım, hipotansiyon, şok. \\
\hline Gebelik/Fötus & -Gebeliğin uzaması, doğumun inhibisyonu, duktus arteriosusun erken kapanması. \\
\hline
\end{tabular}

\section{1.c. Uygunluğu}

AİK kriterlerinden biri olan uygunluk hekimlerin ilaç seçimlerini ATEA işlemi sırasında ve hasta başında son değerlendirme yaparken etkileyecek önemli bir parametredir. İlaç etkileşimleri, bir veya birden çok ilaç/ilaç dışı aktif maddenin birlikte kullanımı sonucu "ilacın etkililiğinde/güvenliliğinde” değişikliklere neden olabilir. Bu olaylar ekonomik yük ve hastaneye yatışlara sebep olabileceği gibi ölümle de sonuçlanabilir $(33,34)$. Polifarmasinin ilaç etkileşimi sebeplerinin başında geldiği ve yaşlı nüfusta daha yoğun görüldüğü bilinmektedir. Türkiyede farklı yıllarda yapılan 11 çalışmanın sonucunda yaşlılarda kişi başına düşen ilaç sayısının 3,25 olduğu tespit edilmiştir (35). Bununla birlikte, 65 yaşın üstündeki hastalarda 9/10'unun bir veya birden fazla ilaç kullandığı ve diş hekimlerine başvuran 65 yaş üstü hasta sayısının giderek arttığı göz önünde bulundurulduğunda, ilaç etkileşimlerini bilmenin önemi açıkça görülmektedir $(33,36)$. Yaşlılarda ilaçların etkilerini değiştiren faktörler arasında vücut su/kas oranının azalması ve yağ oranının artması, CYP enzimlerinin çalışma hızının yavaşlaması ve glomerüler filtrasyon hızının artması sayılabilmektedir. Ayrıca reseptör sayı/duyarlılığının azalıp polifarmasinin artması da önem arz etmektedir (37). NSAİI'ler, araşidonik asit mekanizması yolu ile ve oral antikoagülanların plazma proteinlerine bağlanmasını azaltarak bu ilaçların yan etkilerini arttırırlar. Varfarin kullanan hastalarda NSAİİ alımının Uluslararası Düzeltme Oranı'nını (INR) kanamayı kolaylaştırıcı yönde etkilediği bildirilmiştir $(32,33)$. NSAIII’lerle beta-blokör ilaçlar veya anjiotensin dönüştürücü enzim inhibitörlerinin birlikte kullanımı bu ilaçların antihipertansif etkisini azaltabilir $(32,33,36)$. Lityum preparatları ile NSAİI’lerin birlikte kullanımının kandaki lityum oranını arttırması, terapötik aralığı dar ve ciddi toksisitelere yol açan bir ilaç olan lityum için dikkat edilmesi gereken bir husustur (32, 38). Bazı GİS hastalıklarında diş hekimlerinin NSAİİler ile reçete ettikleri proton pompası inhibitörleri (çoğu durumda gereksiz ve hatalı şekilde kullanılmaktadır) mide pH'sını arttırdığından diğer bazı ilaçların absorpsiyonunu değiştirmektedir (33).

Hastanın yaş grubu da hekimin reçete yazarken uygunluk çerçevesinde düşünmesi gereken bir husustur. Çocuklar; fizyolojik, psikolojik ve zihinsel gelişimlerinin farklılığı bakımından ilaç kullanırken titizlik gösterilmesi 
gereken bir gruptur. Yaş, pek çok farmakokinetik ve farmakodinamik parametreyi değiştirdiğinden erişkinlerin ilaca verdiği yanıtlar çocuklarınkinden çok farklı olabilir. Çocukluk çağında mide boşalma süresinin uzun, mide asit salgısının yetersiz ve barsak motilitesinin düzensiz olduğu göz önünde bulundurulduğunda ilaçların absorpsiyonunun erişkinle aynı olması beklenemez. Ayrıca çocukta vücut sıvı hacmi erişkine göre fazla, plazma proteinlerine bağlanma düşüktür. Plazma proteinlerine bağlanan ilaçların kullanımına dikkat edilmelidir. İlaçların pek çoğunun metabolizmasından sorumlu enzimlerin çalışması da çocuklarda farklılık gösterebilir (39). Örneğin, CYP2D6 adlı karaciğer enzimin, çocuklarda erişkinlerden farklı aktivite göstermesinin de katkısıyla çeşitli ilaç kullanımı sorunlarına yol açabilmektedir. Bu doğrultuda pek çok sağlık otoritesi kodein kullanımını çocuklarda yasaklamıştır (16). Çocuklarda böbreklerden itrah da normalden düşüktür. Major atılımı böbrekler yoluyla olan NSAIII’lerin itrahı çocuklarda değişmektedir ve bu bakımdan dikkatli olunmalıdır (39). Ayrıca asetilsalisilik asidin ateşli durumlar veya viral enfeksiyonlarda kullanımı Reye sendromuna yol açabilir, bu nedenle çocuklarda ve ergenlerde kullanılmaması önerilir $(1,16)$. Non-opioid, non-NSAIII grubundaki parasetamol ile birlikte ibuprofen pediatrik popülasyon da kullanımı daha güvenli kabul edilen analjeziklerdir $(1,16,17)$.

Her ne kadar son yıllarda kullanımı terkedilmeye başlansa da hala pek çok ülkede gebelikte ilaç teratojenite risk sınıflandırması yaygın bir şekilde muhataplarınca kullanılmaktadır. Dünya genelinde bu yönde farklı sınıflandırmalar bulunsa da bunların en bilineni Amerikan İlaç ve Gıda İdaresi (Food and Drug Administration-FDA) başlattığı risk sınıflandırma sistemidir. Bu sınıflandırmaya göre risk "A, B, C, D ve X" kategorilerine ("A" en düşük, "X" ise en yüksek) ayrılır (40). Örneğin, NSAİI’lerin gebelik kategorisi hamileliğin 1. ve 2. trimesterinde "C" iken son trimesterinde "D"dir (41). Aspirinde daha belirgin olmak üzere NSAIII'ler, gebelikte trombosit işlevlerini bozarak kanama riski oluşturabilir, doğum esnasında kullanırsa doğum gecikebilir veya uzayabilir. Yüksek dozlarda fötal duktus arteriosus'un in utero kapanması ve yeni doğanda kalıcı pulmoner hipertansiyona yol açar. Ayrıca yeni doğanda kernikterus riski bulunur. Aspirinin laktasyon döneminde de kullanılması önerilmez. Bebekte Reye sendromuna yol açabilir; bebeğin $\mathrm{K}$ vitamini depoları az ise trombosit fonksiyonlarını bozabilir ve ayrıca hipoprotrombinemi yapabilir $(17,26)$. Gebelikte NSAIİ kullanımı olası yararın ortaya çıkabilecek risklerin üzerinde olduğu durumlar dışında önerilmemektedir. İbuprofen, diklofenak, naproksen gibi NSAİI'lerin anne sütüne düşük oranda geçtiği bilinse de laktasyon döneminde kullanılması da zorunlu haller dışında önerilmez (17).

\section{1.d. Maliyeti}

Diş hekimliğinde analjeziklere akut durumlarda başvurulduğundan, tek bir reçeteyle hastanın tedavi olacağ 1 düşünülür ve söz konusu ilacın kutu maliyeti üzerinden hesap yapılır. "Diş hekimliğinde kullanımı KÜB'ünde doğrudan belirtilen analjeziklerin maliyetleri” Tablo 6'da sunulmuştur. Bu tabloda jenerik isimleri verilen analjeziklerin piyasa eşdeğer ilacı var ise en ucuz olanı dikkate alınmıştır.

Tablo 6. Diş hekimliğinde kullanılan bazı analjeziklerin maliyetleri (2016 yılı Kasım ayı itibarıyla, en düşük kamu fiyatına sahip olan jenerikler üzerinden hesaplanmıştır).

\begin{tabular}{|l|r|r|}
\hline \multicolumn{1}{|c|}{$\begin{array}{c}\text { Farmakolojik Adı } \\
\text { (ATC Kodu) }\end{array}$} & $\begin{array}{c}\text { Kutunun içerdiği } \\
\text { ilaç sayısı }\end{array}$ & Birim kutu fiyatı \\
\hline Parasetamol (N02BE01) & 20 tablet/kutu & $1,05 \mathrm{TL}$ \\
\hline İbuprofen (M01AE01) & 20 tablet/kutu & $3,16 \mathrm{TL}$ \\
\hline Deksketoprofen (M01AE17) & 20 tablet/kutu & $3,89 \mathrm{TL}$ \\
\hline Naproksen (M01AE02) & 10 tablet/kutu & $3,13 \mathrm{TL}$ \\
\hline Diklofenak (M01AB05) & 20 tablet/kutu & $3,17 \mathrm{TL}$ \\
\hline Asetilsalisilik asit (N02BA01) & 20 tablet/kutu & $1,17 \mathrm{TL}$ \\
\hline Diflunisal (N02BA11) & 10 tablet/kutu & $10,18 \mathrm{TL}$ \\
\hline Metamizol (N02BB02) & 20 tablet/kutu & $1,53 \mathrm{TL}$ \\
\hline
\end{tabular}

\section{Non-opioid, non-NSAIII İlaçların Klinik Farmakolojisi}

\section{2.a. Farmakodinami ve Farmakokinetiği}

Non-opioid, non-NSAIII ilaç olarak parasetamol (asetaminofen) orta ve hafif şiddetli ağrıların kontrolü amacıyla kullanılmakta olup aynı zamanda antipiretik etki de gösterir. Antiinflamatuar etkisi yok denecek kadar azdır $(19,22,25)$. Yarılanma ömrü 2-3 saat olan parasetamol 4-6 saat arayla 325-1000 mg (maksimum 4000 mg/gün, erişkin) şeklinde reçete edilebilir (Tablo 4), (18, 22, 25).

Pirazol türevi olan ve diş hekimliğinde de kullanılan analjeziklerden biri olan metamizol uzun süre NSAİ̇ 
olarak değerlendirilmiştir. Ancak yapılan ileri araştırmalar analjezik etkinin başka sistemlerin sistemlerin aktivasyonu ile ilişkili olabileceği yönündedir (42). Bir ön ilaç olan metamizolün yarılanma ömrü 2-3 saat olup yetişkinlerde kullanımı günde 1-4 kez 0,5-1 gram şeklindedir. 6-14 yaş arasındaki çocuklarda günde 1-4 kez 250-375 mg iken 4 ay-5 yaş arası çocuklarda 1-4 kez 50-150 mg şeklindir (17).

\section{2.b. Güvenliği}

Parasetamol, genel olarak gastrik mukozaya zarar vermez. Parasetamol kullanımında nadir de olsa ürtiker benzeri cilt döküntüleri ve diğer alerjik reaksiyonlar görülebilir. En bilinen yan etkisi hepatotoksisitedir (16, 17, 22, 43). Söz konusu hepatotoksisite daha çok yüksek doz ve alkolle birlikte kullanılması durumunda görülür $(1,16,17,22)$. Ayrıca yüksek dozlarda hipoglisemi ve akut renal tübüler nekroz yapabildiği de bildirilmiştir. Nadiren de olsa hematolojik bozukluklara yol açabilir $(17,18)$.

Metamizol kullanımı ile gastrointestinal ülser ve kanama gibi karşıt etkiler pek görülmemektedir. Pirazol türevleri ilaçlar nadiren de olsa duyarlı kişilerde agranülositoz dahil kemik iliği depresyonu etkisi yapabileceğinden dikkatli kullanılmaları esastır $(1,42)$. Metamizol ayrıca Steven Johnson sendromu, hipotansiyon ve böbrek bozukluğu gibi yan etkilere de yol açabilir (17).

\section{2.c. Uygunluğu}

Hepatotoksik özelliklerinden dolayı kronik alkol kullananlarda, karaciğer hastalığı olanlarda parasetamol kullanımından uzak durulmalıdır. Zorunlu hallerde ilgili hekimin görüşü doğrultusunda düşük doz kullanımı gündeme gelebilir. Parasetamol yaşlılarda, çocuklarda, gebe ve emzirenlerde NSAIII’lere göre daha uygun bir analjeziktir. $\mathrm{Bu}$ ve benzeri gerekçelerle diş hekimliğinde sıkça kullanılan analjeziklerden biridir. Parasetamolün gebelik kategorisi “B”dir (17, 20, 41).

\section{Opioid Analjeziklerin Klinik Farmakolojisi}

Opioidler ağrı tedavisinde kullanılan en güçlü ilaç grubudur. Opioid analjeziklere diş hekimliği pratiğinde akut veya kronik, kontrol altına alınamayan ciddi ağrılar olduğunda ihtiyaç duyulabilmektedir. Akut durumlar; intraoperatif, postoperatif ve postravmatik ağrılar, diğer durumlar ise kronik seyreden kanser hastalarında görülen, nöropatik ya da inflamasyon sonucu oluşan ağrılardır (16). $\mathrm{Bu}$ ilaçların etkilerine ve bazı karşı1 etkilerine karşı tolerans gelişmektedir.

Opioidlar kuvvetli ağrı kesici etkilerinin yanı sıra bradikardi, solunum depresyonu ve öfori gibi ciddi yan etkileri bulunduğundan dikkatli kullanılması gereken bir gruptur. Ayrıca GİS'te sekresyonları ve peristaltik hareketleri inhibe etmesi, mide bulantısını ve kusmayı tetiklemesi, öksürük merkezini baskılaması, miyozis yapması iyi bilinen karşıt etkilerindendir $(1,16-20,22)$.

Mide boşalma hızını yavaşlatan opioidler ilaçların absorpsiyonunu değiştirir (33). Opioid analjeziklerin gebelik kategorisi ise "C"dir. Hamilelik döneminde opioid analjezik kullanan kadınların bebeklerinde neonatal yoksunluk sendromu görülme ihtimali bulunmaktadır (44).

Ciddi yan etkileri göz önünde bulundurulduğunda, diş ağrısı olgularının çoğunda opioid analjeziklerin kullanımı uygun değildir (17). Dolayısıyla bu yazıda opioid analjezikler konusunda daha fazla ayrıntıya yer verilmemiş, simüle ATEA işleminde de bu ilaçlar listeye dâhil edilmemiştir.

\section{Sonuç}

Günümüzde analjezik amaçla kullanılan çok sayıda ilaç bulunmaktadır. DH’ler analjezik tedavisi kararı aldığı hastalarına reçete yazarken seçim yapma konusunda zorlanmaktadır. $\mathrm{Bu}$ işlem sırasında ilaca, endikasyona, hastaya ve içinde bulunulan koşullara göre pek çok unsur DH'nin isabetli seçim yapmasını zorlaştırmaktadır. Yazılma oranları, hangisinin tercih edildiği değişse bile analjezikler diş hekimlerinin reçetelerinde yer almaya devam edecektir. $\mathrm{Bu}$ ilaçların seçiminde akılcı yaklaşım sergilenmesi, söz konusu tedavilerin daha başarılı düzenlenmesine olanak sağlar. Bunun için DH'lerin analjeziklerin seçimini etkileyebilecek asgari klinik farmakoloji bilgilerine sahip olması ve seçimini bu bilgiler doğrultusunda yapması gerekir. AİK ilkelerine göre bu işlem, ATEA yöntemi ile kolaylıkla ve isabetle yapılabilir. Böylece hekim KAL oluşturup uzun süreli kullanma olanağına kavuşabilir. KAL tecrübesi kazanan bir DH bunu ilaç tedavisini düzenleyeceği diğer endikasyonlardaki ilaç seçimlerine de kolaylıkla transfer edebilir. Diş hekimliğinde AİK'in yaygınlaştırılması bakımından DH'lerin mezuniyet öncesi ve sonrası eğitimlerinde bu yöntemle ilaç seçimi yapma becerisi kazanmalarına çalışılmalıdır. 
Personal Analgesic List Definition in Accordance with the Rational Use of Medicine for Dentistry

\section{ABSTRACT}

Physicians should prepare their own personal medicine list for each indication before consulting with patients. This approach is essential for rational use of medicine (RUM). One of the most commonly prescribed medicine groups by dentists is analgesics. The purpose of this review is to indicate "how to perform medicine selection based on RUM principles". It is explained with the integration of "personal analgesic list (PAL)" concept to dentistry. PAL establishment is based on 4 main criteria, which are "efficacy, safety, suitability and cost", and the knowledge of clinical pharmacology of analgesics. These principles are followed to choose the best alternative through all medicines. Therefore, dentists might minimize their necessity of knowledge about various kinds of analgesics. It will be easier to learn limited number of medicines in the PAL. In this method, dentists will precisely wise up about a few numbers of medicines, select the most proper one through them and easily remember every details of information that should be given to their patients. Consequently, a dentist with PAL will be able to perform a successful analgesic treatment. This rational approach, initiated with analgesics, might be used by the help of "transfer effect" in other medicine/product groups, such as antibiotics.

Key words: Dentist; Rational use of medicine, Efficacy; Safety; Suitability; Medicine choosing.

\section{Kaynakça}

1. Akıcı A, Uzuner A. Birinci Basamak Sağlık Kurumlarında Çalışan Hekimlere Yönelik Akılcı İlaç Kullanımı. T.C. Sosyal Güvenlik Kurumu Başkanlığı, Ankara. 2013.

2. World Health Organization (WHO). Promoting rational use of medicines: core components. WHO Policy Perspectives on Medicines no5. Geneva, WHO/EDM/2002.3.

3. Akıcı A. Akılcı ilaç kullanımının genel ilkeleri ve Türkiye'deki güncel durum. Türkiye Klinikleri J Pharmacol-Special Topics 2015; 3: 1-10.

4. Aksoy M, Alkan A İF. Sağlık Bakanlığı’nın akılcı ilaç kullanımını yaygınlaştırma faaliyetleri. Turkiye Klin J Pharmacol Special Topics 2015; 3: 19-26.

5. Holloway $\mathrm{K}$, vanDijk L. The world medicines situation 2011-Rational use of medicines. World Health Organization (WHO), Geneva. WHO/EMP/MIE ; 2011:2.2.

6. Karki AJ, Holyfield G, Thomas D. Dental prescribing in Wales and associated public health issues. Br Dent J 2010;210: 21.

7. Cope A, Chestnutt I. Inappropriate prescribing of antibiotics in primary dental care: Reasons and resolutions. Prim Dent J 2014;3: 33-7.

8. Roda RP, Bagán JV, María J, Bielsa S, Pastor EC, Roda RP. Antibiotic use in dental practice . A review. Med Oral Patol Oral Cir Bucal 2007; 12E: 186-92.

9. American Dental Association Council on Scientific Affairs : Combating antibiotic resistance. J Am Dent Assoc 2004; 135: 484-7.

10. Azodo CC, Umoh AO. Analgesics prescription in Nigerian dental healthcare services. Niger J Basic Clin Sci 2013; 10: 8690 .

11. Hanif A. Rational use of analgesics in dental practice. Pakistan Oral Dent J 2016; 36: 282-5.

12. Aydın M, Koyuncuoglu CZ, Kılboz MM, Akıcı A. The rational use of antibiotics in dentistry. Turkiye Klin J Dent Sci 2016; $1-15$.

13. Dar-Odeh NS, Abu-Hammad OA, Al-Omiri MK, Khraisat AS, Shehabi AA. Antibiotic prescribing practices by dentists: A review. Ther Clin Risk Manag 2010; 6: 301-6.
14. Bennadi D. Antimicrobial stewardship - An alarming call in dentistry. Int J Pharm Pharm Sci 2014; 6: 46-9.

15. De Vries TPGM, Henning RH, Hogerzeil HV, Fresle DA. Guide to Good Prescribing. WHO/Action programme on essential drugs, Geneva. 1994.

16. Laskarides C. Update on analgesic medication for adult and pediatric dental patients. Dent Clin N Am 2016; 60: 347-66.

17. Kayaalp O. Türkiye İlaçla Tedavi Kılavuzu 2011-2012 Formüleri (TİK-6). Pelikan Yayıncılık, Ankara. 2011, pp 702719.

18. Becker DE, Phero JC. Drug therapy in dental practice: Nonopioid and opioid analgesics. Anesth Prog 2005; 52: 1409.

19. Hargreaves K, Abbott P V. Drugs for pain management in dentistry. Aust Dent J Suppl 2005; 50:14-22.

20. Mehlisch DR. The efficacy of combination analgesic therapy in relieving dental pain. J Am Dent Assoc 2002; 133: 861-71.

21. Şentürk T. Non-Steroid Anti-İnflamatuar İlaçlar (NSAİ̇̇). İç Hast Derg 2014; 2: 490-5.

22. Goodman \& Gilman's The Pharmacological Basis of Therapeutics, 11th ed. Editors: Brunton LB, Lazo JS, Parker KL. McGraw-Hill, New York. 2005, pp 671-705.

23. Akici A, Gelal A. Birinci basamakta nonsteroid antiinflamatuar ilaçların akılcı kullanımı. Turkiye Klin J Fam Med-Special Topics 2011; 2: 61-70.

24. Green GA. Understanding NSAIDs : From Aspirin to COX-2. Clin Cornerstone 3:50-9.

25. Katzung BG, Masters SB., Trevor AJ. Basic and Clinical Pharmacology, 12th ed. McGraw-Hill, New York. 2012, pp 635-654.

26. Özbudak H, Ünal AZ, Sabuncuoğlu S. Gebelikte non-steroidal antiinflamatuvar ilaçların kullanımının değerlendirilmesi. Marmara Pharm J 2016; 20: 64-71.

27. Barbanoj MJ, Antonijoan RM, Gich I. Clinical pharmacokinetics of dexketoprofen. Clin Pharmacokinet 2001; 40: 245-62.

28. Ong C, Lirk P, Tan CH, Seymour RA. An evidence-based update on nonsteroidal anti-inflammatory drugs. Clin Med 
Res 2007; 5:19-34.

29. Sostres C, Gargallo CJ, Arroyo MT, Staff P, Lanas A, Chief C. Adverse effects of non-steroidal anti-inflammatory drugs (NSAIDs, aspirin and coxibs) on upper gastrointestinal tract. Best Pr Res Clin Gastroenterol 2010; 24 :121-32.

30. Vonkeman HE, Laar MAFJ Van De. Nonsteroidal antiinflammatory drugs: Adverse effects and their prevention. Semin Arthritis Rheum 2010; 39: 294-312.

31. Patrono C, Rocca B. Nonsteroidal antiinflammatory drugs : Past, present and future. Pharmacol Res 2009; 59: 285-9.

32. Oral A. Yaşlılarda osteoartrit tedavisinde nonsteroidal antiinflamatuar ilaçlar: Yan etkiler ve ilaç etkileşimleri. Türk Geriatr Derg 2004; 7: 166-72.

33. Uluoglu C. İlaç etkileşmelerine akılcı yaklaşım. Turkiye Klin J Pharmacol-Special Topics 2015; 3: 65-73.

34. Chiatti C, Bustacchini S, Furneri G, Mantovani L, Cristiani M, Misuraca C, Lattanzio F. The economic burden of inappropriate drug prescribing, lack of adherence and compliance, adverse drug events in older people. Drug Saf 2012; 35: 73-87.

35. Akıcı A. Akılcı ilaç kullanımı ilkeleri doğrultusunda yaşlılarda reçete yazma ve Türkiye'de yaşlilarda ilaç kullanımının boyutları. Geriatr Özel Sayı 2006:19-27.

36. Weinstock RJ, Johnson MP. Review of top 10 prescribed drugs and their interaction with dental treatment. Dent Clin North Am 2016; 60: 421-34.
37. Gelal A. Yaşlılarda Akılcı İlaç Kullanımı. Turkiye Klin J Pharmacol-Special Topics 2015; 3: 57-64.

38. Ament PW, Bertolino JG, Liszewski JL. Clinically significant drug interactions. Am Fam Physician 2000; 61: 1745-54.

39. Akıcı N, Başaran NF. Çocuklarda akılcı ilaç kullanımı. Türkiye Klinikleri J Pharmacol-Special Topics 2015; 3:50-6.

40. Chisolm MS, Payne JL. Management of psychotropic drugs during pregnancy. BMJ 2015; 351: 5918.

41. Servey J, Chang J. Over-the-counter medications in pregnancy. Am Fam Physician 2014; 15: 548-55.

42. Jasiecka A, Maślanka T, Jaroszewski JJ. Pharmacological characteristics of metamizole. Pol J Vet Sci 2014;17: 207-14.

43. Gulmez SE, Larrey D, Pageaux GP, Bernuau J, Bissoli F, Horsmans Y, Thorburn D, McCormick PA, Stricker B, Toussi M, Lignot-Maleyran S, Micon S, Hamoud F, Lassalle R, Jové J, Blin P MN. Liver transplant associated with paracetamol overdose: Results from the seven-country SALT study. Br J Clin Pharmacol 2015; 80: 599-606.

44. Kelly LE, Jansson LM, Moulsdale W, Pereira J, Simpson S, Guttman A, Allegaert K, Askie L, Roukema H, Lacaze T, Davis JM, Finnegan L, Williamson P, Offringa M. A core outcome set for neonatal abstinence syndrome: study protocol for a systematic review, parent interviews and a Delphi survey. Trials 2016; 17: 536. 